УДК 78.036:008(4)'"19',

DOI: https://doi.org/10.31318/2522-4190.2020.129.219721

\title{
КОРЧОВА О. О.
}

Корчова Олена Олександрівна - кандидат мистецтвознавства, доцент, професор кафедри історії світової музики Національної музичної академії України імені П. І. Чайковського (Київ, Україна).

ORCID ID: https://orcid.org/0000-0001-9206-7058

olenakorchova064@gmail.com

(C) Корчова О. О., 2020

\section{ФЕНОМЕН МУЗИЧНОГО МОДЕРНІЗМУ В ЄВРОПЕЙСЬКІЙ КУЛЬТУРІ ХХ СТОЛІТТЯ: ПЕРЕДУМОВИ, ЗАКОНОМІРНОСТІ, ЕТАПИ}

Окреслено розбіжності в розумінні поняття музичного модернізму в західній науковогуманітарній практиці і в українському музикознавстві, охарактеризовано їх історично-політичні причини й естетичну сутність. Наведено аргументи щодо послідовного впровадження поняття музичного модернізму в суміжних наукових сферах — літературознавстві й теорії образотворчого мистецтва. Окремо розкрито смисловий зв'язок модерністського і постмодерністського культурних етапів у європейській історії XX - початку XXI століть. Наголошено на необхідності актуалізувати поняття модернізму як універсальний інструмент дослідження засад цілісності європейської музичної культури XX століття і частково як прогностичний засіб щодо музичних подій найближчого майбутнього. Здійснено стислий огляд розробки вітчизняної теорії музичного модернізму. На основі положень українських дослідниць Н. ГерасимовоїПерсидської, Л. Кияновської, Л. Неболюбової, С. Павлишин, В. Реді, М. Ржевської запропоновано авторську дефініцію музичного модернізму з акцентом на перехідній природі цього епохального мистецького феномена і на його належності до культури посткласичного типу. Визначено хронологічні межі півстолітньої доби музичного модернізму (кінець 1880 - кінець 1930-х років). Окреслено кілька культурно-історичних передумов формування художньої системи музичного модернізму на засадах полістильового мистецького устрою, а також зважаючи на результати перегляду класичного естетичного ідеалу. Обгрунтовано цілісність музичної мови доби модернізму і виняткову роль у ній різноманітних стильових елементів. Сформульовано закономірності музичного модернізму як системного культурного явища першої половини XX століття. Здійснено внутрішню періодизацію музичного модернізму з урахуванням паралельних щодо часу розгортання еволюційних процесів (відповідний механізм автор визначає як «хронологічну стрету»). Завдяки аналізу стильових проявів, спільних для кожного періоду, виділено й охарактеризовано наскрізні стильові комплекси.

Ключові слова: європейська культура, посткласичний тип культури, модернізм, стиль, музичний модернізм, еволюція, періодизація, музична мова.

Постановка проблеми. Поняття модернізму як мистецького явища по-різному представлено у загальносвітовому науковому просторі. У західній гуманітарній традиції XX століття воно зазнало послідовної розробки, набувши статусу універсальної категорії, придатної для глибокого аналізу сучасних культурно-мистецьких процесів. Такий підхід зберігається і в перші десятиліття XXI століття, перебіг яких 
актуалізує проблему спадкоємності модерністських і постмодерністських естетичних принципів. Натомість у радянському і почасти пострадянському науковому просторі поняття модернізму побутувало на інших засадах: відповідно до ідеологічних настанов, воно зазнавало певних смислових трансформацій - від штучного протиставлення державній концепції соціалістичного реалізму у 1930-х роках до свідомого ігнорування шляхом тривалої термінологічної стагнації у 1990-х і пізніше.

Сьогодні в українському музикознавстві з усією очевидністю назріла потреба переглянути й актуалізувати це явище. Вона транслюється завдяки конкретному науковому запиту, а саме - можливості сформувати за нинішньої часової дистанції цілісний погляд на культурно-мистецький процес XX століття та його ключові події. Це дасть можливість зрозуміти системність відповідних художніх результатів і розкрити (принаймні частково) механізм стадіального переходу найближчого культурного минулого в теперішнє, даючи змогу навіть прогнозувати найближче культурне майбутнє.

Аналіз останніх досліджень та публікацій. Сучасна західна теорія музичного модернізму представлена винятковою за обсягом кількістю досліджень різного видового і жанрового спрямування. Щодо формування базових музично-історичних підходів, провідну роль відіграли дослідження К. Дальхауза ${ }^{1}$, Д. Олбрайта ${ }^{2}$, Р. $_{\text {Тарускіна }}{ }^{3}$ Зразком практичного застосування поняття музичного модернізму 6 монографія Г. Данузера, присвячена творчості Г. Малера ${ }^{4}$. Найновіші ідеї містять матеріали Круглого столу «Модернізм та інше», видані з передмовою Л. Тайнбрідж (L. Tunbridge) ${ }^{5}$. Зразком переконливої популяризації поняття сприймається бестселер А. Росса «Далі шум. Слухаючи музику XX століття» ${ }^{6}$.

Досліджень, дотичних до проблематики музичного модернізму, серед праць українських авторів не так багато. Тут засновницею можна вважати С. Павлишин, зокрема iï навчальний посібник «Музика XX століття» ${ }^{7}$. Вагомий внесок у розробку теорії, особливо щодо особливостей проявів модернізму у вітчизняній музичній культурі першої третини XX століття, належить М. Ржевській 8

Авторка цієї статті розпочала досліджувати феномен музичного модернізму в роботі «Модерністичні витоки сучасного композиторського раціоналізму» ${ }^{9}$ і в кількох пізніших публікаціях, присвячених зарубіжній та українській історї музики першої половини XX століття.

${ }^{1}$ Dahlhaus C. Nineteenth-Century Music / trans. by J. Bradford Robinson. Berkeley : University of California Press, 1989. 417 p.

${ }^{2}$ Modernism and Music : An Anthology of Sources / ed. with a commentary by D. Albright. Chicago : University Chicago Press, 2004. 440 p.

${ }^{3}$ Taruskin R. The Oxford history of Western music : in 6 vols. Oxford : Oxford University Press, 2004. 4272 p.

${ }^{4}$ Danuser H. Gustav Mahler und seine Zeit. Laaber : Laaber-Verlag, 1991. 380 p. (Grosse Komponisten und ihre Zeit).

${ }^{5}$ Tunbridge L. Introduction // Journal of the Royal Musical Association. 2014. Vol. 139. Issue 1 : Round Table: Modernism and its Others. URL: https://www.tandfonline.com/doi/full/10.1080/02690403.2014.887301 (accessed: 16.09.2019).

${ }^{6}$ Росс А. Дальше - шум. Слушая XX век / пер. с англ. М. Калужского, А. Гиндиной. Москва : ACT ; Corpus, 2014. URL: http://loveread.ec/read_book.php?id=47518\&p=1 дата обращения: 16.05.2020).

${ }^{7}$ Павлишин С. С. Музика двадцятого століття : навч. посібник. Львів : БаК, 2005. 232 с.

${ }^{8}$ Ржевська М. Ю. На зламі часів: музика Наддніпрянської України першої третини ХХ століття у соціокультурному контексті епохи. Київ : Автограф, 2005. 352 с.

${ }^{9}$ Корчова О. О. Модерністичні витоки сучасного композиторського раціоналізму // Науковий вісник Національної музичної академії імені П. І. Чайковського : зб. наук. пр. Вип. 73 : Музична творчість та наука в історичному просторі. Київ, 2008. С. 16-22. 
Важливим кроком стало практичне застосування поняття модернізму як інструмента дослідження в дисертаційних працях науковців молодшого покоління, зокрема К. Краснощок ${ }^{1}$. Важливою в актуалізації цього поняття стала стаття Л. Русакової «Модернізм: тлумачення у вітчизняному музикознавстві» ${ }^{2}$, хоча вона й не претендує на повноту інформації. Однак, незважаючи на важливість названих праць, в українській науці не сформульовано чітких і комплексних методологічних положень щодо дефініції поняття модернізму, його часової атрибуції, внутрішньої періодизації тощо.

Мета статті - охарактеризувати і на цій основі запровадити поняттєво-термінологічний дискурс музичного модернізму, який відповідає сучасним специфічним науковим і загальним професійним потребам. Завдання статті - актуалізувати термінологічні питання, пов'язані з поняттям музичного модернізму, окреслити межі і контури відповідного культурно-мистецького феномена ХХ століття, виявити його естетичну природу, розкрити закономірності функціонування і внутрішню еволюційну динаміку.

Наукова новизна статті зумовлена тим, що в ній викладено авторську концепцію музичного модернізму, узгоджену з усталеними підходами, розробленими у західній музикології, але цілком самостійну в певних конкретних позиціях.

Виклад основного матеріалу. Наукова картина історії світової, передусім європейської музичної культури першої половини XX століття, до якої звертається сучасний український дослідник, $\epsilon$ результатом колективних зусиль вчених кількох поколінь. Вони ретельно дослідили й структурували фактичні дані, узагальнили провідні художні процеси, утвердили певний іменний стандарт у грунтовних працях різних жанрів, передусім у підручниках і начальних посібниках. Серед них у поточному освітньому процесі чільне місце належить таким, як: масштабне за обсягом музично-історичного матеріалу видання пізнього радянського часу («Музыка ХХ века: Очерки (1890-1945)»)3; більш актуальна серія «История зарубежной музыки» (зокрема випуск шостий за редакцією В. Смирнова ${ }^{4}$; авторські розробки представників українського музикознавства старшого покоління («Французька музична культура рубежу XIX-XX століть» Т. Гнатів ${ }^{5}$ $\mathrm{i}$ «Музыкальная культура Германии и Австрии рубежа XIX-XX веков» Л. Неболюбової6); фундаментальні праці 2000-х років московських авторів («Техника современной ком-

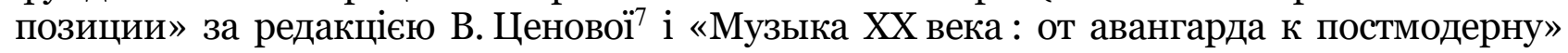

${ }^{1}$ Краснощок К. Ю. Композиторська інтерпретація художньо-естетичного спадку Жана Кокто в творчості представників французького модернізму ХХ століття : дис. ... канд. мистецтвознавства : спец. 17.00.03 Музичне мистецтво / Харківський нац. ун-т мистецтв ім. І. П. Котляревського. Харків, 2012. 16 с.

2 Русакова Л. В. Модернізм: тлумачення у вітчизняному музикознавстві // Проблеми взаємодії мистецтва, педагогіки та теорії і практики освіти : зб. наук. пр. / Харк. держ. ун-т мистецтв ім. І. П. Котляревського. Вип. 34. Харків, 2012. С. 86-102.

${ }^{3}$ Музыка XX века : Очерки (1890-1945) : в 2 ч., 5 кн. / Всесоюзный науч.-исслед. Ин-т искусствознания; Ленинградский гос. ин-т театра, музыки и кинематографии Министерства культуры РСФСР ; ред. Д. Житомирский. Москва : Музыка, 1976-1987.

${ }^{4}$ История зарубежной музыки : учеб. для консерваторий / Ленингр. гос. консерватория им. Н. А. Римского-Корсакова ; каф. истории музыки. Вып. 6 : Начало XX века - середина XX века / ред. В. Смирнов. Москва : Музыка, 1999. 626 с.

${ }^{5}$ Гнатів Т. Ф. Музична культура Франції рубежу XIX-XX століть: Клод Дебюссі, Моріс Равель : навч. посібник для вищ. і серед. муз. навч. закладів. Київ : Муз. Україна, 1993. 207 с.

${ }^{6}$ Неболюбова Л. С. Музыкальная культура Германии и Австрии рубежа XIX-XX веков: Густав Малер, Рихард Штраус : учеб. пособие для высш. и сред. спец. учеб. заведений. Киев : Муз. Україна, 1990. $164 \mathrm{c}$.

${ }^{7}$ Теория современной композиции : учеб. пособие для студ. вузов, обучающихся по спец. 051400 Музыковедение / Московская гос. консерватория им. П. И. Чайковского ; отв. ред. В. Ценова. Москва : Музыка, 2005. 616 с. (Academia XXI. Учебники и учебные пособия по культуре и искусству). 
М. Висоцької та Н. Григор'євої${ }^{1}$ ). До найновіших підручників належить «Музика XXXXI століть. Східна Європа та українське зарубіжжя» О. Берегової².

Та незважаючи на докладне розкриття музично-історичних подій першої половини XX століття, сучасна наукова ситуація потребує їх подальшої розробки, удосконалення, уточнень, особливо гостро - узагальнень на основі певного наскрізного поняття. Таке поняття здатне охопити значний масив музичних явищ певного хронологічного періоду і надати йому ознак системності, логічної зумовленості, зрештою, смислової цілісності. Адже в радянських, а часом і в пострадянських наукових парадигмах властивістю культури й мистецтва всього XX століття, його відмінністю від попередніх епох традиційно вважалась відсутність згаданих характеристик. Досить поширеним було твердження про довільне поєднання найрізноманітніших мистецьких феноменів, зокрема й стильових, у їх численних функціональних комбінаціях. Художній устрій цього поєднання, на думку багатьох упереджених спостерігачів, позбавлений впорядкованості, більше того, керованості порівняно з устроєм класичного мистецтва. Зрозуміло, що подібні застарілі твердження нині потребують перегляду.

Питання «пошуку наукового імені», тобто універсального терміна, придатного для дослідження мистецьких феноменів будь-якої доби, набуває виняткової гостроти, коли аналіз охоплює явища, належні до поточної культурної ситуації. Не дивно, що проблема найменування поширюється і на музичну реальність нашого часу - зразка XXI століття. Наявність відповідного професійного виклику для українського музикознавства констатує одна з його провідних представниць Л. Кияновська: «...неназване явище часто залишається неосмисленим, викликає велику плутанину в теоретичних підходах до нього, породжує масу спекуляцій та категоріальних перекручень, а відтак втрачає якісь істотні характеристики»³.

В окресленому контексті термін «модернізм» перебирає на себе роль наукової категорії, так би мовити, зовнішнього вжитку, адже ії активно застосовують фахівці суміжних з музикознавством дисциплін для загальної характеристики художніх явищ першої половини XX століття - літературознавці, експерти з історії образотворчого мистецтва тощо. Їхня практика має кілька логічних підстав. По-перше, слово «модернізм», яке загалом має тривалу історію, у сучасному розумінні постало в середовищі мистецтвознавців на початку XX століття, а отже, є ровесником доби. По-друге, як поняття широкого вжитку, воно відрізняється необхідною смисловою й етимологічною прозорістю, адже представляє семантику оновлення, осучаснення, руху вперед. Потретє, в колишньому радянському й нинішньому пострадянському культурному середовищі поняття «модернізм» зазнало складних перипетій в історичному побутуванні: схематично і водночас символічно відповідний сюжет легко вкласти в тріаду: «народження - смерть - відродження». Відтак, в Україні теорія модернізму, як виразного культурно-мистецького феномена, зазнала фальсифікації і все ще переживає процес реабілітації. Зрештою, очевидним, але мало конкретизованим залишається зв'язок цього поняття з його культурно-історичним нащадком - постмодернізмом, значно більш узвичаєним у професійному середовищі.

\footnotetext{
${ }^{1}$ Высоцкая М. С., Григорьева Г. В. Музыка ХХ века: от авангарда к постмодерну : учеб. пособие. Москва : Московская консерватория, 2011. 440 с.

${ }^{2}$ Берегова О. М. Музика XX-XXI століть. Східна Європа та українське зарубіжжя. Кн. 1. Ч. 1. Київ : НМАУ ім. П. І. Чайковського, 2012. 296 с.

${ }^{3}$ Кияновська Л. О. Який сьогодні стиль надворі? // Науковий вісник Національної музичної академії України імені П. І. Чайковського : зб. наук. пр. Вип. 119 : Наукові діалоги з Н. О. ГерасимовоюПерсидською / ред.-упоряд. І. Г. Тукова. Київ, 2017. С. 74.
} 
У тих випадках, коли термін «модернізм» не становить концепційної основи в українських дослідженнях музично-історичного процесу ХХ століття, він застосовується в лінійному вимірі як своєрідна понятійна канва для зовнішнього обрамлення розрізнених стильових феноменів. Лише зрідка читач може натрапити на більш розгорнуту й предметну характеристику музичного модернізму. Однією з перших це здійснила львівська дослідниця С. Павлишин. Хоча в іiї посібнику «Музика двадцятого століття» термін «модернізм» і не посідає чільного місця, однак він є важливим маркером музично-історичного аналізу, на що вказує зміст вступного і завершального розділів книги. Зокрема, С. Павлишин констатує: «Двадцяте століття починається від модернізму (Стравінського, Дебюссі, Равеля, Бартока, Прокоф'єва, Малєра, Шенберга, Веберна), який намагався заперечити, але не знищити традицію» ${ }^{1}$. Таким чином авторка чи не першою серед українських колег співвідносить прізвища Дебюссі й Равеля (а за необхідності, й інших композиторів-сучасників) з модерністським понятійним контекстом, а побіжно фіксує принцип музичної періодизації XX століття, що полягає в поділі всього належного до нього історичного часу на три взаємопов'язані етапи: модернізм - авангардизм - постмодернізм.

Послідовною прихильницею модерністської парадигми є М. Ржевська, авторка монографії, присвяченої українській музичній культурі першої третини ХХ століття. На це, зокрема, вказує великий розділ їі книги під назвою «Від модернізму в Україні до українського модернізму». У своєму тлумаченні модернізму М. Ржевська виділяє найбільш проблемні аспекти його сучасної теорії: складність долання наслідків минулих мистецтвознавчих практик, розбіжності між вітчизняною і зарубіжною науковими традиціями тощо.

Уникаючи глибинних дефінітивних процедур щодо самого поняття модернізму, М. Ржевська натомість пильно аналізує прилегле термінологічне поле, особливо вкрай складне співвідношення понять «модернізм» і «авангард». Однак, згідно з традицією, вона схильна розглядати модернізм у лінійному ракурсі, як сукупність різноманітних стильових течій і напрямів, «перелік яких <...> є досить варіабельним» ${ }^{2}$. При цьому їі більшою мірою зацікавлює те, що їх відрізняє, ніж те, що споріднює і поєднує.

Спробу вперше узагальнити наукові положення щодо походження й хронологічних меж музичного модернізму здійснено в статті харківської дослідниці Л. Русакової «Модернізм: тлумачення у вітчизняному музикознавстві». Однак у публікації, мета якої позиціонується як «проблематизація поняття “модернізм” у вітчизняній музикології» ${ }^{3}$, значно ширше представлені погляди російських вчених - Г. Григор'євої, Т. Лєвої, І. Скворцової. І все ж, Л. Русакова цілком справедливо стверджує: «...на сьогодні Постмодернізм у вітчизняному музикознавстві нібито слідує чи не одразу за Романтизмом, оскільки така необхідна ланка у ланцюжку історичного наслідування, як “Модернізм”, присутня в ньому скоріше у виді натяку для посвячених, ніж у реальному “фізичному тілі” музикознавчої науки» ${ }^{4}$

На основі сказаного можна резюмувати: сучасна українська теорія музичного модернізму перебуває в стадії первинного оформлення, ознаками якої є епізодичність

\footnotetext{
${ }^{1}$ Павлишин С. С. Музика двадцятого століття. С. 226. Тут і далі при цитуванні україномовних джерел збережено орфографію оригіналу.

2 Ржевська М. Ю. На зламі часів: музика Наддніпрянської України першої третини ХХ століття у соціокультурному контексті епохи. Київ : Автограф, 2005. С. 144.

3 Русакова Л. В. Модернізм: тлумачення у вітчизняному музикознавстві. С. 86.

4 Там само. С. 90.
} 
і вибірковість застосування поняття, відсутність чіткого визначення, зосередженість на лінійному емпіричному підході.

Пошук сучасної дефініції музичного модернізму потребує, серед іншого, врахування перехідної культурно-історичної природи тогочасної епохи, грунтовно дослідженої свого часу Л. Неболюбовою ${ }^{1}$. До неї долучилася В. Редя, яка розглядає перехідні закономірності на художньому матеріалі російської культури початку ХХ століття, так званої Срібної доби. В іï монографії головним поняттям у дослідженні перехідних явищ постає інтегративність різних видових мистецьких компонентів: «Багаторівнева інтеграція стає знаком епохи. Перебуваючи в постійному контакті, література, музика, живопис, театральне мистецтво в усіх його різновидах значно розширюють свої художні можливості на основі інтегративних взаємодій»².

Специфіка досліджуваного феномена передбачає, з-поміж іншого, залучення суміжного 3 музикознавчою сферою поняття «типу культури», тобто виходу за межі суто музикознавчої парадигми. Цього потребують темп, масштаб і щільність культурних змін, характерних для XX століття, адже їх неможливо пояснити, оперуючи лише фактами з історії музики. Відомо, що культура посткласичного типу суттєво відрізняється від ï класичного аналога, вона функціонує за законами, близькими до новітніх наукових принципів, зокрема й у сфері точних дисциплін, а також на засадах множинності, децентралізації і плюралізму традицій.

Серед фахівців, які наголошують на глибинних зв’язках між науковим і творчим сегментами посткласичної культури, найавторитетніша у світі українська дослідниця Н. Герасимова-Персидська, авторка статті «XXI століття і musica mundana». Вочевидь, ця стаття відіграє програмну роль в усвідомленні світоглядних засад сучасного музикознавства. Авторка зазначає: «Для нас особливо важливим $\epsilon$ те, що радикальні перетворення в музиці відбулись у час революційного перегляду розуміння всесвітніх законів, зміни наукової, а звідси, й світоглядної парадигми»³.

Ідеї Н. Герасимової-Персидської послідовно розвиває І. Тукова, передусім шляхом залучення спорідненої категорії некласичного. Дослідниця вважає «некласичність» базовою характеристикою загального стану науки й мистецтва нашого часу: «Множинність, темпоральність $і$ складність - це саме ті властивості, котрі, на нашу думку, можуть характеризувати й цілісне уявлення про музичне мистецтво ХХ початку XXI століть. У такий же спосіб, як сходяться різні частини головоломки, утворюючи єдність, зійшлись у своїх визначальних якостях музичне мистецтво та природничі науки, демонструючи спільну інтелектуально-духовну спрямованість розвитку (курсив оригіналу. - О.К.) ${ }^{4}$.

Спираючись на ці наукові положення, а також залучаючи досвід культурології, беручи до уваги різноманітні підходи до феномена музичного модернізму, часом

${ }^{1}$ Див.: Неболюбова Л. С. Системно-стилевые проблемы австро-германского романтизма (типология поздних этапов в истории искусства) // Исторические и теоретические проблемы музыкального стиля : тематич. сб. науч. трудов. Киев : КГК им. П. И. Чайковского, 1993. С. 55-71.

${ }^{2}$ Редя В. Я. «Есть тонкие властительные связи...». Интегративные процессы в музыке Серебряного века : монография. Киев : НАКККіМ, 2010. С. 22.

${ }^{3}$ Герасимова-Персидська Н. О. XXI століття і musica mundana // Часопис Національної музичної академії України імені П. І. Чайковського : наук. журн. Київ, 2008. № 1 (1). С. 91.

${ }^{4}$ Тукова И. Г. Неклассическая парадигма музыки и естествознания XX - начала XXI веков // Науковий вісник Національної музичної академії імені П. І. Чайковського : зб. наук. пр. Вип. 119 : Наукові діалоги з Н. О. Герасимовою-Персидською / ред.-упоряд. І. Г. Тукова. Київ, 2017. С. 102-103. 
подібні, а часом контроверсійні, усвідомлюючи виняткову гостроту відповідної проблематики, пропонуємо таку дефініцію: музичний модернізм - це епохальний період у розвитку європейського музичного мистецтва від кінця 80-х років XIX століття до кінця 30-х років XX століття, протягом якого відбувається поступовий перехід від класичного до посткласичного типу музичної культури, запроваджується її полістильовий устрій і формуються засади сучасної музичної мови.

Зважаючи на глобальний вимір культурних змін, подвійною естетичною настановою для митців, представників епохи модернізму, стає оновлення старого (власне, модернізація досвіду минулого) та відкриття нового (у вигляді модусу, спрямованого у майбутнє). Це відбувається на тлі перегляду усталених естетичних цінностей, що раніше були визнані як художній ідеал класичного мистецтва: «Для модернізму філософська категорія прекрасного втрачає основоположне значення: краса в цьому мистецтві може бути наявною або відсутньою взагалі, що не впливає на цінність того чи іншого витвору модерністського мистецтва» ${ }^{1}$.

Якщо в мистецтві класичної доби головним критерієм художньої досконалості була категорія прекрасного, то в модерністському мистецтві ним є естетична категорія нового. Вона поширюється на всі, без винятку, музично-поняттєві сфери, зокрема такі, як краса звучання. Унікальність і самодостатність новітнього звучання - позакласичного, позавпорядкованого, часто й позатонального - у своїх теоретичних текстах намагалися пояснити композитори XX століття різних поколінь, з особливою ж наполегливістю - активісти повоєнного авангардизму.

Прикладом унаочнення зазначених естетичних зрушень можна вважати порівняння двох творів, еталонних щодо втілення музично-прекрасного. Вони написані на початку й наприкінці XX століття: Adagio із П’ятої симфонії Г. Малера (1902) і вокальноелектронна композиція С. Райха «Proverb» (1995). Незважаючи на кардинальні розбіжності звуковисотного і темброво-фактурного вирішення, та й загалом художнього й інтонаційного облаштування, у названих творах непорушно зберігається смисловий каркас піднесеної ліричності - витончений пластичний мелос у поєднанні з емоційнопросвітленою образністю.

Такі зв’язки на відстані з легкістю унаочнюються нині, коли стає зрозуміло, що музичний модернізм, як і літературно-поетичний, живописний та інші видові аналоги, всупереч поширеним твердженням, оперує єдиною мистецькою мовою. Відповідні інтонаційні контури з плином часу проступають усе чіткіше і сприймаються все більш органічно. Адже тепер, коли спливає друге десятиліття XXI століття і хронологічна відстань бачення зростає до максимуму, завдання ідентифікації будь-якого музичного твору першої половини XX століття, належного саме до свого історичного часу, стає елементарним, навіть коли неможливо миттєво визначити ім'я композитора або ж однозначно назвати обраний ним стильовий напрям. Інструментом ідентифікації постають об'єктивні, епохальні ознаки музичної лексики, які у сприйнятті слухача наступного століття переважають над суб'єктивними, внутрішніми деталями композиторського висловлювання.

Проте визнання цього факту затримується в часі - справа ускладнюється тим, що спільна мова музичного модернізму, породжена специфічною культурою посткласичного типу, має особливу природу. Ідеться про генетичну множинність, синтетичність, апріорну «полігенність» модерністської звукової матерії (власне, поліматеріі), яку утворюють контрастні художні елементи як складові певних лексично-стильових

\footnotetext{
${ }^{1}$ Берегова О. О. Музика XX-XXI століть. Східна Європа та українське зарубіжжя. Кн. 1. Ч. 1. С. 12.
} 
субсистем. Їх комбінація в певному музичному опусі щоразу зумовлена унікальним комплексом чинників - конкретним творчим задумом, поточною фазою біографічного процесу автора, тогочасною естетичною ситуацією на європейському континенті, у країні, в оточенні митця тощо.

3 певною обережністю можна припустити, що полістильові утворення в цілісній музичній мові доби модернізму відіграють роль спільного семантично-інтонаційного фонду - власне, як у музиці класико-романтичного періоду це відбувалось із жанрово-інтонаційними джерелами, найбільш поширеними в композиторській практиці. Звісно, це не означає, що композитори доби модернізму відмовились від останніх як таких, що втратили актуальність, але свідчить, що жанрово-інтонаційні джерела перейшли на інший, більш опосередкований рівень ідейно-образного представництва художнього задуму щодо полістильових компонентів.

Не менш важливою передумовою мовно-лексичної цілісності музичного модернізму була єдність сукупної мистецької системи, відтворена в численних стильових аналогіях одразу на кількох структурних рівнях: у різних видах мистецтва, у різних національних культурах, в різних мистецьких спільнотах, зрештою, в різних персональних творчих біографіях. Щоправда, конфігурація взаємодії модерністських стильових аналогій була винятково складною, мінливою і безмежно далекою від класичних законів симетрії чи тотожності. Загалом модерністські стильові явища вкрай нерівномірно поширювались у спільному культурно-мистецькому середовищі. В одних випадках при цьому одночасно формувалися споріднені феномени (зокрема стиль «модерн» в ужитковій сфері, архітектурі і музиці); в інших, навпаки, розгортання аналогічних феноменів було підпорядковане послідовним часовим процесам (символізм поетичний значно випередив появу музичного, як імпресіонізм у живописі передує імпресіонізму музичному). Часом пошук стильових аналогій взагалі позбавлений сенсу, зважаючи на принципову відмінність між художнім устроєм окремих видів мистецтва (як у випадку зіставлення живописного абстракціонізму з близькими за спрямованістю музичними новаціями, передусім атональністю; хоча в цьому випадку зближення персональних лідерів було граничним, беручи до уваги тісні творчі й особисті контакти В. Кандинського і А. Шенберга).

Дороговказом у визначенні закономірностей музичного модернізму є математично чітка формула Н. Герасимової-Персидської, згідно з якою «цілісність як якість

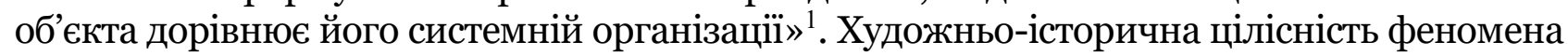
музичного модернізму справді зумовлена його системністю. Аналіз загального масиву фактичних даних дає змогу виокремити системні засади музичного модернізму, зокрема такі:

- Модернізм тісно пов'язаний з минулим (епохою романтизму) і майбутнім (авангардним і постмодерністським етапами наступної епохи) завдяки трансформації провідних художніх традицій, які утворюють рухливе тіло музичної культури ХХ століття.

- Модернізм, як і кожен попередній епохальний мистецький період, демонструє насичену внутрішню еволюцію, протягом якої докорінно змінюється сам устрій художнього буття й мислення. Зокрема, поступово скасовується сакральний ритуал професійного виконавства, дещо послаблюється інститут авторства, переглядається характер співвідношення часу і простору в музичному творі, переосмислюються його текстові межі і способи фіксації тощо.

\footnotetext{
${ }^{1}$ Герасимова-Персидська Н. О. XXI століття і musica mundana. С. 91.
} 
- Модернізм грунтується на полістильовому принципі функціонування художньої культури, тому розвивається як сукупність багатьох стильових явищ (що їх у повсякденному культурному побуті називають «-ізмами»). Частина $з$ них має музичні версії, інші - ні, як, скажімо, абстракціонізм, сюрреалізм тощо.

- Модерністські стильові явища розвиваються одночасно за хронологічною горизонталлю, заміняючи один одного, та за континуальною вертикаллю, одномоментно співіснуючи в межах мистецького твору, індивідуального стилю, національної школи.

- У середині епохи модернізму співіснують і протистоять один одному два культурних вектори (термін російського дослідника О. Соколова) - модерний (поміркований) і авангардний (радикальний), взаємодія яких спричиняє його внутрішню художню динаміку. Прикладом цього є певні «антагоністичні» щодо міри радикалізму, сповідуваного митцями, композиторські пари: К. Дебюссі - Г. Форе; А. Шенберг Ф. Шрекер; О. Скрябін - С. Рахманінов; С. Прокоф'єв - М. Мясковський; Б. Лятошинський - В. Косенко.

- Жоден із представників модернізму як полістильового феномена не є носієм одного («чистого») стилю, але кожен проходить складний шлях пошуків власної творчої ідентичності, що для митця передбачає момент (моменти) стильового самовизначення, а для дослідника - пошук певної «стильової формули» його творчості.

- Модерністське музичне мистецтво поступово відходить від принципу європоцентризму й інтенсивно збагачується інтонаційними елементами неєвропейських культур (Північної та Латинської Америки, Далекого Сходу, Океанії, навіть Африки), а також світоглядними принципами неєвропейських релігій (буддизм, іслам).

Для подальшого дослідження феномена музичного модернізму розглянемо його внутрішню художню динаміку, яку становлять сума світоглядних, соціальних, естетичних, стильових і технологічних зрушень, які періодично спричиняли якісні перетворення. Передусім варто наголосити, що історично послідовний перебіг музичного модернізму розгортався досить наочно, внаслідок чого в середині епохи сформувалися помітні (принаймні для сучасного спостерігача) і художньо компактні часові блоки. Результатом відносно регулярних, хоча й не завжди усвідомлених кроків уперед поставали певні сутнісні зміни в колективному композиторському мисленні, зумовлені переважно об’єктивними історичними причинами. Сьогодні це надає можливість створити своєрідну «пунктирну схему» зазначених змін, тобто намітити внутрішню періодизацію музичного модернізму.

Ï̈ розробка здійснюється відповідно до двох елементарних принципів, які регулюють будь-які процеси людської діяльності: тріадності складу кожного з життєвих / культурних явищ та паралельності їх розгортання. Крім того, музична аудиторія має можливість розглядати прояви модерністської процесуальності крізь призму суто професійного сприйняття, тобто уявляти їх як поліфонічну еволюційну комбінацію, власне, як хронологічну стрету, що буде відображено далі.

Як уже зазначалось, загальні часові межі музичного модернізму було визначено як п’ятдесятилітній період: від кінця 1880-х років, коли постали перші характерно модерністські опуси Е. Саті та К. Дебюссі, - до кінця 1930-х років, коли з початком Другої світової війни відбувся своєрідний культурно-цивілізаційний обрив, i, до речі, були написані перші характерно авангардистські твори Дж. Кейджа, найстаршого серед головних представників авангардизму. Тут виникає певна арифметична проблема, адже п'ятдесят років не поділяються рівно на три стадіальні періоди, натомість вони поділяються навпіл, групуючись навколо «умовного 1914 року», не тільки як початку 
Першої світової війни, а також як хронологічної точки першого у XX столітті глобального культурного «збою». Визначаємо цю дату як центральну в розвитку, як «середину середини», кульмінаційну точку в еволюції музичного модернізму. Художні події, що тяжіють до 1914 року (прем’єри «Місячного П’єро» А. Шенберга і трьох балетних вистав «Весни священної» І. Стравінського, «Пополудневого відпочинку Фавна» на музику К. Дебюссі та «Дафніса і Хлої» М. Равеля), маркують найбільш щільний момент періодизації музичного модернізму, коли на серцевину центрального етапу накладаються, відповідно, завершення раннього і початок пізнього етапів. Саме так утворюється та виразна хронологічна стрета, яка ілюструє складну поліфонічну композицію перших музичних десятиліть XX століття (схема 1).

Схема 1

Хронологічна стрета внутрішньої періодизації музичного модернізму

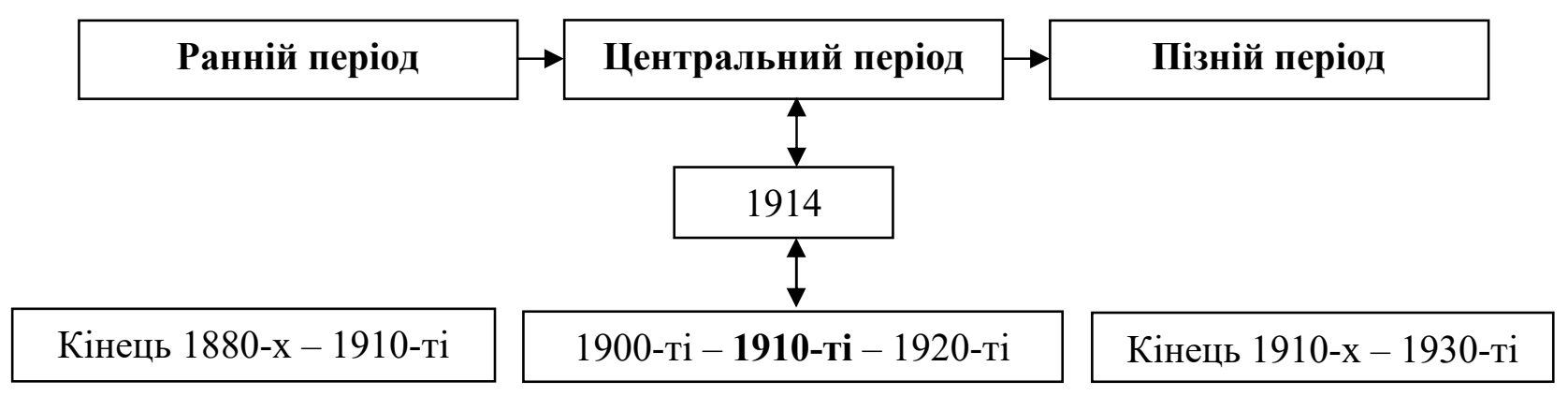

Насичений інтенсивним культурним рухом відрізок часу - від кінця 1880-х до середини 1910-х (умовного 1914 року) - становить ранній період музичного модернізму. Тут в епіцентрі подій постають імпресіонізм - символізм (зважаючи на сучасні наукові підходи, їх варто розглядати як неподільний стильовий тандем). Суттєво доповнюють картину постромантичні тенденції, що відображаються у творчості Г. Форе, К. Дебюссі, частково у М. Равеля та їх численних послідовників. На периферії стильових новацій раннього музичного модернізму перебувають стиль модерн і окремі «авторські» явища, зокрема космізм О. Скрябіна і так званий ліричний реалізм Дж. Пуччіні.

Сукупно утворюється чітко упізнаваний і досить однорідний стильовий комплекс, який можна назвати поетичним, оскільки головною ознакою раннього модернізму на образно-емоційному рівні постає поетичність композиторського висловлювання, а на рівні композиторської ідеології - естетизація дійсності. Загальне, закономірне для доби модернізму ускладнення параметрів музичної мови в цей час розгортається відносно повільно, маючи характер м'якої дії, реалізованої передусім завдяки модальності, запровадженій у сфері звукової організації. Показовим моментом також $\epsilon$ збереження в гармонічному полі «колективного» модерністського опусу опорної ролі консонансу, який функціонує на засадах поступового, але неухильного віддалення від функційної моделі класичного гармонічного устрою.

Водночас, лідерська композиторська спільнота залучає кілька художньо актуальних конструктів, виразниками яких є некласичні звукоряди (пентатонічний, цілотоновий, хроматичний та інші), позначені яскравою своєрідністю звучання. Очевидно, їх поєднує акустична характерність, здатність передавати нові, небанальні й нелінійні за смислом інтонаційні образи. Окреслені зміни в ладогармонічній сфері (а саме вона протягом кількох попередніх століть активувала класичну систему музичного мислення) знаменують початок визначального для всього ХХ століття контроверсійно 
спрямованого руху композиторських зацікавлень: замість історично виробленого «інстинкту» утвердження висотної й функціональної визначеності звука виникає прагнення виявити його фізичний обсяг і самодостатню акустичну сутність, тобто просування до тембрового мислення, до колористики-сонористики.

Наступне двадцятиліття, 1900-1920-ті роки, охоплює найбільш радикальний, центральний період музичного модернізму, зважаючи на його культурні результати. Базовим стильовим явищем у ньому, безумовно, є експресіонізм, остаточно утверджений нововіденською композиторською школою, зокрема творчістю А. Шенберга, А. Берга й А. Веберна. Суміжними явищами постають дадаїзм Е. Саті, фовізм тогочасного І. Стравінського й раннього С. Прокоф’єва, «варваризм» Б. Бартока, футуризм Дж. Б. Прателли й Л. Руссоло. Новоутворений стильовий комплекс за всіма його ознаками можна назвати екстремальним.

Як головний меседж цього етапу, оформлений в досить дратівливі для втомленого слуху тогочасного меломана художні форми, проступає в композиторській творчості напруження душі й інтелекту. Саме воно супроводжує мистецьке сприйняття першої у XX столітті світової катастрофи, проживання жахливої передвоєнної і воєнної дійсності. У музиці цього періоду, «пікового» не тільки в хронологічному, а й у багатьох інших сенсах, закарбовано кризовий стан артистичної свідомості та її небезпечне наближення до межі художньо розумного, навіть художньо можливого. Відображаючи тогочасні суспільно-психологічні реалії, музичний модернізм демонструє не бачену досі невротичність композиторського висловлювання. Спільною рефлексією митців покоління Великої війни, як їі називають на Заході, прогнозовано стає катастрофізація дійсності, тому не дивує різке ускладнення музичної мови, їі майже «некероване» загострення, розрив із традиційними слуховими установками, перехід за червоні лінії пересічного сприйняття. Замість відносно м'яких жестів, характерних для попереднього етапу, модерністська культура вдається до жорстких прийомів радикальної композиторської практики - перегляду і скасування тональності як такої, надання переваги в гармонічній грі дисонансу, рішучого відходу від масиву усталених нормативів: формальних, що стосувалися, наприклад, виконавських складів для різних жанрів, i сутнісних, які відповідали за лексичне навантаження музичного твору, скажімо, метроритмічних чи фактурних.

Однією з визначальних подій цього періоду стає кристалізація внутрішнього музичного феномена, який фокусує в собі системні професійні зрушення: феномена сучасної композиторської техніки, передусім серійної техніки (в авторському варіанті А. Шенберга - додекафонної). Більш віддаленою музично-історичною перспективою постає регламентація творчого процесу взагалі і творчого акту зокрема, зміщення до явищ «строгої природи»: раціональних технік, акустично-експериментальних практик, випадків зрощення музики з наукою й технологією - вони стануть нормативними в музиці середини ХX століття.

Від кінця 1910-х до кінця 1930-х років - триває пізній період музичного модернізму. Його стильовим осердям стає потужне і багато в чому консенсусне явище неокласицизму, емблемою якого прийнято вважати творчість П. Гіндеміта й К. Орфа, хоча не варто відкидати досягнення С. Прокоф’єва й І. Стравінського у становленні відповідного художнього канону. Доповнюють стильову палітру повоєнного (згодом з'ясується, що лише міжвоєнного) періоду значно більш «екзотичні» в плані інтонаційного походження явища: неофольклоризм, урбанізм, конструктивізм, динамізм, нова речевість, нова простота. 
Спільну естетичну платформу для всіх названих різновидів становить антиромантичний комплекс художніх ідей, що метафорично постає на повоєнних руїнах, на тлі глобальних потрясінь, світоглядних розчарувань і докорінно змінених життєвих настанов. Тогочасні антиромантичні позиції як епохальний чинник спонукають композиторів відмовитися від домінування суб’єктивно-емоційних джерел вислову й відійти від традиційних ліричних констант музичної образності (любовної, психологічно-рефлексивної, побутово-пейзажної тощо), але водночас підштовхують до пошуку нових, більш раціональних творчих мотивацій. Відтак, естетична природа стильових новацій пізнього модернізму дає змогу об’єднати їх у раціональний стильовий комплекс.

Видається, що новою цінністю, а відтак і потребою тогочасного європейського композитора стає примирення з дійсністю, що виливається у відновлення емоційної рівноваги і знов набутого позитивізму мислення. Закономірним результатом таких змін стає своєрідне технологічне «вирівнювання» музичної мови: реабілітація тонального методу внаслідок прив'язки сучасного 12-ступеневого звукоряду до єдиного центру, а також розміщення його в «анархічному» середовищі сучасної акордики. Досягнутий у такий спосіб консенсус щодо ладотонального устрою поширюється й на сферу гармонії, у якій дисонанс рівно уживається з консонансом, а функціональна логіка - з модальною. Жорсткість, різкість, кострубатість висловлювання, які вже неможливо було «відіграти» назад, бо вони назавжди увійшли у спільну художню свідомість епохи, сприймалися в ті роки як суттєво адаптовані і загалом прийнятні звучності завдяки естетичній упорядкованості старовинних жанрів та етичній гармонії вічних тем (і ті й інші були запозичені тогочасними композиторами з духовної спадщини попередніх епох). Відносне заспокоєння колективної творчої ініціативи і пожвавлення діалогу з далеким минулим намічали нову глобальну тенденцію до відкриття новітнього, постмодерністського всесвіту з його плюралістичною ідеологією й ретроспективними інтенціями.

Висновки. Отже, феномен музичного модернізму охарактеризований тут як центральний масив подій в історії європейської музики першої половини ХХ століття. Він потребує подальшого багаторівневого наукового аналізу, надаючи підстави для найрізноманітніших музикознавчих інтерпретацій. Запропонований підхід $\epsilon$ лише одним iз можливих, однак за умови послідовного оперування самим поняттям. Утім, певні висновки лежать буквально на поверхні. Їх озвучує С. Привалов, автор одного із сучасних підручників із зарубіжної музичної літератури, єдиного на сьогодні, у якому поняття модернізму застосоване як титульне: «...ХХ століття стало епохою повного, майже вичерпного втілення ідеї “музичного прогресу”, вираженої в “модернізації”, переоснащенні композиторів найновішими засобами виразності. Якщо раніше традиції оновлювалися завдяки накопиченню поступових змін (а періодичні якісні стрибки зберігали тісний зв’язок із попереднім художнім етапом), то минуле століття піднесло новизну майже до самодостатнього культу, служити якому окремі зухвалі автори вирушали далеко за межі музики. Отже, поняття модернізму <...> розуміється вкрай широко - як праг-

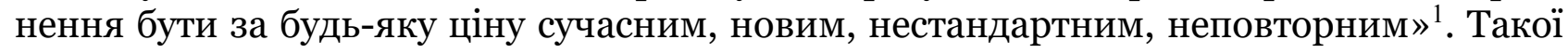
ж міри широти застосування та глибини розробки потребує сьогодні і теорія музичного модернізму, долучена до категоріального апарату українського музикознавства.

${ }^{1}$ Привалов С. Б. Зарубежная музыкальная литература, конец ХІХ века - XX век. Эпоха модернизма. С. 10-11. 


\section{СПИСОК ВИКОРИСТАНӦ̈ ЛІТЕРАТУРИ}

1. Берегова О. О. Музика XX-XXI століть. Східна Європа та українське зарубіжжя. Кн. 1. Ч. 1. Київ : НМАУ ім. П. І. Чайковського, 2012. 296 с.

2. Высоцкая М. С., Григорьева Г. В. Музыка XX века: от авангарда к постмодерну : учеб. пособие. Москва : Московская консерватория, 2011. 440 с.

3. Герасимова-Персидська Н. О. XXI століття і musica mundana // Часопис Національної музичної академії України імені П. І. Чайковського : наук. журн. Київ, 2008. № 1 (1). С. 90-97.

4. Гнатів Т. Ф. Музична культура Франції рубежу XIX-XX століть : Клод Дебюссі, Моріс Равель : навч. посібник для вищ. і серед. муз. навч. закладів. Київ : Муз. Україна, 1993. 207 с.

5. История зарубежной музыки : учебник для консерваторий / Ленингр. гос. консерватория им. Н. А. Римского-Корсакова. Вып. 6 : Начало XX века - середина XX века / ред. В. Смирнов. Москва : Музыка, 1999. 626 с.

6. Кияновська Л. О. Який сьогодні стиль надворі? // Науковий вісник Національної музичної академії України імені П. І. Чайковського : зб. наук. пр. Вип. 119 : Наукові діалоги 3 Н. О. Герасимовою-Персидською / ред.-упоряд. І. Г. Тукова. Київ, 2017. С. 65-90.

7. Корчова О. О. Модерністичні витоки сучасного композиторського раціоналізму // Науковий вісник Національної музичної академії України імені П. І. Чайковського : зб. наук. пр. Вип. 73 : Музична творчість та наука в історичному просторі. Київ, 2008. С. 16-22.

8. Краснощок К. Ю. Композиторська інтерпретація художньо-естетичного спадку Жана Кокто в творчості представників французького модернізму ХХ століття : автореф. дис. ... канд. мистецтвознавства : спец. 17.00.03 Музичне мистецтво / Харківський нац. ун-т мистецтв ім. І. П. Котляревського. Харків, 2012. 16 с.

9. Музыка XX века (1890-1945) : очерки : в 2 ч., 5 кн. / Всесоюзный науч.-исслед. ин-т искусствознания; Ленинградский гос. ин-т театра, музыки и кинематографии Министерства культуры РСФСР ; ред. Д. Житомирский. Москва : Музыка, 1976-1987.

10. Неболюбова Л. С. Музыкальная культура Германии и Австрии рубежа XIX-XX веков: Густав Малер, Рихард Штраус : учеб. пособие для высш. и сред. спец. учеб. заведений. Киев : Муз. Україна, 1990. 164 с.

11. Неболюбова Л. С. Системно-стилевые проблемы австро-германского романтизма (типология поздних этапов в истории искусства) // Исторические и теоретические проблемы музыкального стиля : тематич. сб. науч. трудов. Киев : КГК им. П. И. Чайковского, 1993. С. 55-71.

12. Павлишин С. С. Музика двадцятого століття : навч. посібник. Львів : БаК, 2005. 232 с.

13. Привалов С. Б. Зарубежная музыкальная литература, конец XIX века - XX век. Эпоха модернизма модернизма : учебник для старших и выпускных классов детских музыкальных школ, колледжей и лицеев. Санкт-Петербург : Композитор, 2010. 533 с.

14. Редя В. Я. «Есть тонкие властительные связи...». Интегративные процессы в музыке Серебряного века : монография. Киев : НАКККіМ, 2010. 320 с.

15. Ржевська М. Ю. На зламі часів: музика Наддніпрянської України першої третини XX століття у соціокультурному контексті епохи. Київ : Автограф, 2005. 352 с.

16. Русакова Л. В. Модернізм: тлумачення у вітчизняному музикознавстві // Проблеми взаємодії мистецтва, педагогіки та теорії і практики освіти : зб. наук. пр. / Харк. держ. ун-т мистецтв ім. І. П. Котляревського. Харків, 2012. Вип. 34. С. 86-102.

17. Росс А. Дальше - шум. Слушая XX век / пер. с англ. М. Калужского, А. Гиндиной. Москва : ACT ; Corpus, 2014. URL: http://loveread.ec/read_book.php?id=47518\&p=1 (дата обращения: 16.05.2020).

18. Теория современной композиции : учеб. пособие для студентов вузов, обучающихся по специальности 051400 Музыковедение / Московская гос. консерватория им. П. И. Чайковского ; отв. ред. В. Ценова. Москва : Музыка, 2005. 616 с. (Academia XXI: учебники и учебные пособия по культуре и искусству).

ISSN 2522-4190 (print) Науковий вісник Національної музичної академії України імені П. І. Чайковського. 2020. Вип. 129 
19. Тукова И. Г. Неклассическая парадигма музыки и естествознания XX - начала XXI веков // Науковий вісник Національної музичної академії імені П. І. Чайковського : зб. наук. пр. Вип. 119 : Наукові діалоги з Н. О. Герасимовою-Персидською / ред.-упоряд. І. Г. Тукова. Київ, 2017. С. 91-105.

20. Dahlhaus C. Nineteenth-Century Music / trans. by J. Bradford Robinson. Berkeley : University of California Press, 1989. 417 p.

21. Danuser H. Gustav Mahler und seine Zeit. Laaber : Laaber-Verlag, 1991. 380 p. (Grosse Komponisten und ihre Zeit).

22. Modernism and Music. An Anthology of Sources / ed. with a commentary by D. Albright. Chicago : University Chicago Press, 2004. 440 p.

23. Taruskin R. The Oxford history of Western music. 6 vols. Oxford : Oxford University Press, 2004. 4272 p.

24. Tunbridge L. Introduction // Journal of the Royal Musical Association. Vol. 139. 2014.

Issue 1: Round Table: Modernism and its Others. URL: https://www.tandfonline.com/doi/full/10.1080/02690403.2014.887301 (accessed: 16.09.2019).

\section{REFERENCES}

1. Berehova, O. (2012). Music of the 20-21 centuries. Eastern Europe and Ukrainian abroad [Muzyka XX-XXI stolit. Skhidna Yevropa ta ukrainske zarubizhzhia]. Book 1. Part 1. Tchaikovsky National Music Academy of Ukraine. Kyiv, 296 p. [in Ukrainian].

2. Vysockaja, M. and Grigor'eva, G. (2011). Music of the $20^{\text {th }}$ century: from the avant-garde to the postmodern [Muzyka XX veka: ot avangarda k postmodernu]: textbook allowance. Moscow: Moskovskaja konservatorija, 440 p. [in Rassian].

3. Gerasymova-Persydska, N. (2008). $21^{\text {th }}$ century and musica mundana [XXI stolittia i musica mundane]. In: Journal of the Tchaikovsky National Music Academy of Ukraine [Chasopys Natsionalnoi muzychnoi akademii Ukrainy imeni P. I. Chaikovskoho]. Issue 1 (1), pp. 90-97 [in Ukrainian].

4. Hnativ, T. (1993). Musical culture of France at the turn of the $19^{\text {th }}-20^{\text {th }}$ centuries: Claude Debussy, Maurice Ravel [Muzychna kultura Frantsii rubezhu XIX-XX stolit: Klod Debiussi, Moris Ravel]: textbook manual for higher and among music textbook institutions. Kyiv: Muzychna Ukraina, 207 p. [in Ukrainian].

5. Smirnov, V., ed. (1999). History of foreign music [Istorija zarubezhnoj muzyki]: textbook for conservatories. Leningrad State Conservatory named after N. A. Rimsky-Korsakov. Issue 6: Beginning of the $20^{\text {th }}$ century - middle of the $20^{\text {th }}$ century [Nachalo XX veka - seredina XX veka], ed. V. Smirnov. Moscow: Muzyka, 626 p. [in Rassian].

6. Kyianovska, L. (2017). What is the style outside today? [Yakyi sohodni styl nadvori?]. In: Scientific herald of Tchaikovsky National Music Academy of Ukraine Scientific herald of Tchaikovsky National Music Academy of Ukraine [Naukovyi visnyk Natsionalnoi muzychnoi akademii Ukrainy imeni P. I. Chaikovskoho]. Iss. 119: Scientific dialogues with N. O. Gerasymova-Persydska [Naukovi dialohy z N. O. Herasymovoiu-Persydskoiu], ed. by I. Tukova. Kyiv, pp. 65-90 [in Ukrainian].

7. Korchova, O. (2008). Modernist origins of modern compositional rationalism [Modernistychni vytoky suchasnoho kompozytorskoho ratsionalizmu]. In: Scientific herald of Tchaikovsky National Music Academy of Ukraine [Naukovyi visnyk Natsionalnoi muzychnoi akademii Ukrainy imeni P. I. Chaikovskoho]. Iss. 73: Musical creativity and science in historical space. [Muzychna tvorchist ta nauka v istorychnomu prostori]. Kyiv, pp. 16-22 [in Ukrainian].

8. Krasnoshchok, K. (2012). Composer's interpretation of the artistic and aesthetic heritage of Jean Cocteau in the works of representatives of French modernism of the $20^{\text {th }}$ century [Kompozytorska interpretatsiia khudozhno-estetychnoho spadku Zhana Kokto v tvorchosti predstavnykiv frantsuzkoho modernizmu XX stolittia]: The dissertation author's abstract for gaining the degree of the Candidate of Art Criticism by specialty 17.00.03 Music Art. Kharkiv National Kotlyarevsky University of Arts. Kharkiv, 16 p. [in Ukrainian]. 
9. Zhitomirskii, D. ed. (1976-1987). Music of the twentieth century (1890-1945) [Muzyka XX veka (1890-1945)]. Essays, in 2 vls., 5 books, ed. D. Zhytomyr; All-Union Research Institute of Art History; Leningrad State Institute of Theater, Music and Cinematography of the Ministry of Culture of the RSFSR. Moscow: Muzyka [in Russian].

10. Neboljubova, L. (1990). Musical culture of Germany and Austria at the turn of the $19^{\text {th }}$ $20^{\text {th }}$ centuries: Gustav Mahler, Richard Strauss [Muzykal'naja kul'tura Germanii i Avstrii rubezha XIX-XX vekov: Gustav Maler, Rihard Shtraus]: textbook allowance for higher and middle special textbook routine. Kyiv: Muz. Ukraina, 164 p. [in Russian].

11. Neboljubova, L. (1993). Systemic and stylistic problems of Austro-German romanticism (typology of late stages in the history of art). [Sistemno-stilevye problemy avstro-germanskogo romantizma (tipologija pozdnih jetapov v istorii iskusstva)]. In: Historical and theoretical problems of musical style [Istoricheskie i teoreticheskie problemy muzykal'nogo stilja]: thematic sat of the scientific works. Kyiv, pp. 55-71 [in Russian].

12. Pavlyshyn, S. (2005). Music of the twentieth century [Muzyka dvadtsiatoho stolittia]: textbook manual. Lviv: BaK, 232 p. [in Ukrainian].

13. Privalov, S. (2010). Foreign musical literature, the end of the $19^{\text {th }}$ century - the $20^{\text {th }}$ century. The era of modernism [Zarubezhnaya muzykal'naya literatura, konets XIX veka - XX vek. Epokha modernizma]: a textbook for senior and graduate classes of children's music schools, colleges and lyceums. Sankt-Petersburg: Kompozitor, 533 p. [in Russian].

14. Redja, V. (2010). "There are subtle power ties ...". Integrative processes in the music of the Silver Age ["Est' tonkie vlastitel'nye svjazi...". Integrativnye processy v muzyke Serebrjanogo veka]: a monograph. National Academy of Culture and Arts Management. Kyiv, 320 p. [in Russian].

15. Rzhevska, M. (2005). At the turn of time: the music of Dnieper Ukraine in the first third of the twentieth century in the socio-cultural context of the era [Na zlami chasiv: muzyka Naddniprianskoi Ukrainy pershoi tretyny XX stolittia u sotsiokulturnomu konteksti epokhy]. Kyiv: Avtohraf, 352 p. [in Ukrainian].

16. Ross, A. The Rest is Noise. Listening to the twentieth century [Dal'she-shum. Slushaja XX vek], transl. from English by M. Kaluzkskyi, A. Gindina. Moscow: AST; Corpus, 2014. Available at: http://loveread.ec/read_book.php?id=47518\&p=1 (accessed: 16.05.2020) [in Russian].

17. Rusakova, L. (2012). Modernism: interpretation in Ukrainian musicology [Modernizm: tlumachennia u vitchyznianomu muzykoznavstvi]. In: Problems of interaction of art, pedagogy and theory and practice of education: coll. science work [Problemy vzaiemodii mystetstva, pedahohiky ta teorii i praktyky osvity]. Kharkiv State Kotlyarevsky University of Arts. Iss. 34. Kharkiv, pp. 86-102 [in Ukrainian].

18. Tsenova, V. ed. (2005). Theory of modern composition [Teorija sovremennoj kompozicii]: textbook manual for university students majoring in 051400 Musicology, Tchaikovsky Moscow State Conservatory. Moscow: Muzyka, 616 p. [in Russian].

19. Tukova, I. (2017). Non-classical paradigm of music and natural science of the $20^{\text {th }}-$ beginning of the $21^{\text {st }}$ centuries [Neklassicheskaja paradigma muzyki i estestvoznanija XX - nachala XXI vekov]. In: Scientific herald of Tchaikovsky National Music Academy of Ukraine [Naukovyi visnyk Natsionalnoi muzychnoi akademii Ukrainy imeni P. I. Chaikovskoho]. Iss. 119: Scientific dialogues with N. O. Gerasymova-Persydska [Naukovi dialogi z N. O. Gerasimovoju-Persydskoju], ed. by I. Tukova. Kyiv, pp. 91-105 [in Ukrainian].

20. Dahlhaus, C. (1989). Nineteenth-Century Music. Trans. by J. Bradford Robinson. Berkeley: University of California Press, 417 p. [in English].

21. Danuser, H. (1991). Hustav Mahler and His Time [Gustav Mahler und seine Zeit]. LaaberVerlah, 380 p. (The Graite Composers and Their Time) [Grosse Komponisten und ihre Zeit] [in German].

22. Albright, D. ed. (2004). Modernism and Music An Anthology of Sources. Chicago: University Chicago Press, 440 p. [in English]. 
23. Taruskin, R. (2004). The Oxford history of Western music. In. 6 vols. Oxford: Oxford University Press, 4272 pp. [in English].

24. Tunbridge, L. (2014). Introduction. In: Journal of the Royal Musical Association. Vol. 139. Issue 1: Round Table: Modernism and its Others. Available at: https://www.tandfonline.com/ doi/full/10.1080/02690403.2014.887301 (accessed: 16.09.2019) [in English].

\section{КОРЧЕВАЯ Е. А.}

Корчевая Елена Александровна - кандидат искусствоведения, доцент, профессор кафедры истории мировой музыки Национальной музыкальной академии Украины имени П. И. Чайковского (Киев, Украина).

ORCID ID: https://orcid.org/0000-0001-9206-7058

olenakorchova064@gmail.com

DOI: https://doi.org/10.31318/2522-4190.2020.129.219721

\section{ФЕНОМЕН МУЗЫКАЛЬНОГО МОДЕРНИЗМА В ЕВРОПЕЙСКОЙ КУЛЬТУРЕ ХХ СТОЛЕТИЯ: ПРЕДПОСЫЛКИ, ЗАКОНОМЕРНОСТИ, ЭТАПЫ}

Актуальность статьи определяется главной целью исследования и состоит в том, что феномен музыкального модернизма приобретает конкретные характеристики применительно к его дефиниции, временной атрибуции и внутренней периодизации, а также в научном внедрении соответствующего понятийно-терминологического дискурса.

Методы исследования: исторический - раскрывает общее содержание и художественную специфику избранного отрезка европейской музыкальной истории; культурологический - фокусирует исследование на категории типа культуры, что позволяет поднять его на более высокий уровень музыкально-исторического обобщения; системный - воплощает собой наиболее результативный подход к анализу разрозненного, но весьма насыщенного культурного фактажа, а также утверждает актуальный взгляд на музыкальную историю ХХ века; феноменологический - придаёт исследованию определённые понятийные контуры и способствует смысловой дифференциации использованных в процессе анализа разноуровневых культурно-художественных явлений.

Главные результаты и выводы предложенного в статье исследования музыкального модернизма позволяют рассмотреть данный феномен как эпохальный период в европейской культуре первой половины прошлого столетия; раскрыть его переходную сущность в движении европейского искусства от классического к постклассическому типу культуры; утвердить фундаментальную роль внутренне-стилевых процессов построения модернистской музыкальной культуры как множественной, децентрализованной и плюралистичной по своей природе; ввести понятие «стилевой комплекс», которым маркируются ранний, центральный и поздний этапы эволюции музыкального модернизма; очертить круг кардинальных изменений в сфере академической музыкальной лексики первой половины XX века и определить сквозные линии дальнейшего культурного развития.

Научная новизна статьи обусловлена презентацией в общих чертах авторской концепции музыкального модернизма, согласованной с устоявшимися подходами западной музыкологии, но самостоятельной по ряду конкретных позиций.

Ключевые слова: европейская культура, постклассический тип культуры, модернизм, стиль, музыкальный модернизм, эволюция, периодизация, музыкальный язык. 


\section{OLENA KORCHOVA}

Korchova, Olena - Candidate of Art Criticism, Associate Professor, Professor at the Department of World Music History at the Tchaikovsky National Music Academy of Ukraine (Kyiv, Ukraine).

ORCID ID: https://orcid.org/0000-0001-9206-7058

olenakorchova064@gmail.com

DOI: https://doi.org/10.31318/2522-4190.2020.129.219721

\section{The Phenomenon of MUSiCAL Modernism in the European CUlture OF The 20 ${ }^{\mathrm{TH}}$ Century: Prerequisites, Patterns, Stages}

The relevance of the study and scientific novelty of the research are determined by its main objective and consist in revealing the phenomenon of musical modernism by discovering its specific characteristics in terms of definition, temporal attribution and internal periodization, as well as in the introduction of appropriate conceptual and terminological discourse.

Methodology of the research: historical method reveals the general content and artistic specificity of the selected segment of European musical history; culturological method focuses research on the category of type of culture, which allows to raise it to a much higher level of musical-historical generalization; systemic method embodies the most effective approach to the analysis of disparate, but extremely rich cultural facts, as well as introduces a relevant view of the musical history of the twentieth century; phenomenological method provides the study of certain conceptual contours and promotes the semantic differentiation involved in the analysis of multilevel cultural and artistic phenomena.

Conclusions. The main results and conclusions of the study of musical modernism proposed in the article allow us to consider this phenomenon as an epoch-making period in European culture of the first half of the last century; to reveal its transitional essence in the movement of European art from the classical to the postclassical type of culture; to affirm the fundamental role of intra-stylistic processes of development of modernist musical culture as multiple, decentralized and pluralistic in nature; to introduce the concept of "stylistic complex", which marks the early, central and late stages of the evolution of musical modernism; to outline the circle of cardinal changes in the field of academic musical vocabulary of the first half of the $20^{\text {th }}$ century and to define cross-cutting lines of further cultural development.

Significance of the research. The scientific novelty of the article is due to the presentation in general terms of the author's concept of musical modernism, consistent with the well-established approaches of Western musicology, but independent in a number of specific positions.

Keywords: European culture, postclassical type of culture, modernism, style, musical modernism, evolution, periodization, musical language 